\title{
PENGARUH KONSELING KELOMPOK DENGAN PENDEKATAN BEHAVIORAL TEKNIK KONTROL DIRI UNTUK MENGURANGI KECANDUAN GAME ONLINE PADA SISWA KELAS $X$ TKR SMK MUHAMMADIYAH 6 ROGOJAMPI
}

\author{
Khusnul Khotimah ${ }^{1)}$, Endang Minarni ${ }^{2)}$ \\ Fakulkas Keguruan Ilmu dan Pendidikan, Universitas PGRI Banyuwangi \\ Email : husnulajhaa@gmail.com ${ }^{1}$ \\ Email : endangmr249@yahoo.co.id ${ }^{2}$
}

\begin{abstract}
Abstrak
Kecanduan game online adalah salah satu bentuk kecanduan yang bersifat non-physical, ditunjukan dengan perilaku tidak sehat yang kompulsif atau perilaku yang dilakukan secara terus-menerus dalam memainkan game online untuk mendapat kepuasan tersendiri sehingga akan sulit berhenti atau membatasinya meski perilaku tersebut menyebabkan beberapa masalah sosial atau emosional. Oleh karena itu penting bagi siswa dalam meningkatkan kontrol dirinya yang rendah. Tujuan dari penelitian ini adalah untuk menguji pengaruh konseling kelompok dengan pendekatan behavioral teknik kontrol diri untuk mengurangi kecanduan game online pada siswa SMK Muhamadiyah 6 Rogojampi kelas X TKR. Jumlah sampel yang digunakan adalah 20 siswa yang kecanduan game online. Metode penelitian ini menggunakan rancangan Non equivalent Pretest-Posttest Control Group Design.
\end{abstract}

Kata Kunci: Kecanduan game online, Teknik Kontrol diri

\begin{abstract}
Online game addiction is one form of addiction that is non-physical, indicated by the behavior of unhealthy or compulsive behavior that is done continuously in playing games online to get its own satisfaction so it will be difficult to stop or restrict even though the behavior causes some social problems or emotional. Therefore it is important for students to improve their low selfcontrol. The purpose of this study was to examine the effect of group counseling with behavioral approach of self control techinique to reduce online game addiction on students SMK Muhammadiyah 6 Rogojampi class X $T K R$. The number of samples used is 20 students who are addicted to online games. This research menthod uses non equivalent design pretest-posttest control group design.
\end{abstract}

Keywords: Online game addiction, Self control technique

\section{PENDAHULUAN}

Pendidikan merupakan salah satu usaha setiap bangsa untuk meningkatkan kualitas sumber daya manusia sehingga membantu memperlancar pelaksanaan pembangunan nasional Indonesia. Usaha pendidikan ini ditujukan untuk mengembangkan cipta, rasa, dan karsa yang ada sehingga setiap manusia diharapkan mampu menghadapi 
ISBN: 978-602-72362-7-1

tantangan sesuai dengan tuntutan perubahan kehidupan lokal, nasional, maupun kehidupan global. Pasal 1 ayat (1) Undang-Undang Nomor 20 Tahun 2003 tentang Sistem Pendidikan menjelaskan bahwa, pendidikan adalah usaha sadar dan terencana untuk mewujudkan suasana belajar dan proses pembelajaran agar peserta didik secara aktif mengembangkan potensi dirinya untuk memiliki kekuatan spiritual keagamaan, pengendalian diri, kepribadian, kecerdasan, akhlak mulia, serta keterampilan yang diperlukan dirinya, masyarakat, bangsa dan negara. Pendidikan sangatlah penting untuk kehidupan seseorang, karena dengan pendidikan kita dapat mengenal kehidupan lebih luas dan menambah mindset atau pola pikir seseorang, khususnya pada masa remaja pendidikan sangat di butuhkan.

Masa Remaja merupakan masa transisi, masa penuh emosi dan adakalanya emosinya meledak-ledak, yang muncul karena adanya pertentangan nilai-nilai. Emosi yang menggebu-gebu ini adakalanya menyulitkan, baik si remaja maupun bagi orangtua atau orang dewasa di sekitarnya. Pada masa ini remaja sangat sensitive dalam aspek pergaulan sebayanya. Masa remaja juga merupakan masa dimana mereka ingin diakui oleh teman sebaya sehingga mereka selalu beraktualisasi diri secara berlebihan, yang pada akhirnya berdampak negatif pada dirinya dan orang lain. Masa remaja terbagi menjadi masa remaja awal (11/12-16/17) dan remaja akhir (16/17-18 tahun).

Perkembangan teknologi saat ini ditunjukan dengan berbagai aspek dalam kehidupan, salah satunya ditunjukkan dengan adanya internet. Internet saat ini telah menjadi salah satu aspek penting dalam kehidupan sehari-hari. Banyak kegiatan atau tujuan dalam penggunaan internet sendiri. Mulai dari jejaring sosial, browsing, instant messaging, mengadakan berita terkini, jual beli, vidio streaming, bahkan untuk bermain game ( Asosiasi Penyelenggara Jasa Internet Indonesia, 2015).

Penggunaan internet di Indonesia terus meningkat, terutama jika dibandingkan dengan hasil riset APJII mengenai hal yang sama di tahun 2012 . Dalam penelitian mengenai profil pengguna internet di Indonesia tahun 2012, APJII melaporkan penetrasi pengguna internet di Indonesia adalah 24,23\%. Sementara survei di tahun 2014 menunjukkan penetrasi pengguna internet di Indonesia adalah 34,9\% atau sekitar 88,1 juta pengguna di Indonesia (APJII, 2015). Berdasarkan penelitian tentang profil pengguna internet di Indonesia yang dilakukan APJII pada maret 2015, banyak alasan untuk 
ISBN: 978-602-72362-7-1

mengakses internet. Salah satunya adalah untuk hiburan atau bersenangsenang dengan prosentase sebesar $32,6 \%$ dengan aktivitas game online sebesar $10,1 \%$.

Game Online menurut kim dkk game atau (permainan) dimana banyak orang yang dapat bermain pada waktu yang sama melalui jaringan komunikasi online atau internet (dalam Azis 2011:3). Selanjutnya Winn dan Fisher mengatakan bahwa Multiplayer online game adalah pengembangan dari single player dengan bentuk dan metode yang sama serta konsep yan sama dengan game lain akan tetapi dapat dimainkan oleh banyak pemain dalam waktu yang sama. Salah satu game yang terpopuler saat ini adalah Mobile Legends.

Menurut Yee banyak faktor yang mendorong seseorang untuk bermain game online diantaranya achievement (prestasi), social (sosial), dan immersion (penghayatan). Gamer atau pemain game terdorong untuk bermain game karena menginginkan pengakuan akan prestasinya dalam bermain game yang dilakukan dengan mengatasi rintangan sulit sehingga meraih tingkatan yang lebih tinggi atau item yang langka dengan sebaik- baiknya. Dorongan ini akan membuat seseorang terus bermain bahkan bisa sampai lupa waktu, sehingga dorongan ini dapat menimbulkan perilaku kecanduan.
Selain itu, adanya faktor sosial yang mendorong pemain untuk menemukan pemain lain sehingga dapat membantunya dalam bermain game atau sekedar berbagi strategi dan informasi. Terakhir adalah faktor penghayatan yang mendorong pemain untuk lebih memahami dan mendalami game yang sedang dimainkan. Pada saat mencoba game online dan merasa penasaran dengan kelanjutannya atau tingkatantingkatan selanjutnya, pemain akan mencoba untuk memahami dan mendalami game tersebut. Sehingga, pemain akan mencoba strategi-strategi yang beragam agar berhasil dalam game tersebut dan diakui prestasinya (dalam Feprinca 2008:3).

Kecanduan game online merupakan salah satu jenis bentuk kecanduan yang disebabkan oleh teknologi internet atau yang lebih dikenal dengan internet addictive disorder. Penelitian yang dilakukan oleh Walter melabel kecanduan internet sebagai perilaku obsesif kompulsif, berdasarkan kesamaan dengan kecanduan judi dan belanja yang kompulsif, karena gangguan ini tidak sesuai dengan ketergantungan kimia. Namun, sangat sedikit yang diketahui tentang kecanduan internet secara keseluruhan (dalam Azis, 2011:14).

Kecanduan game online menjadi aktivitas yang paling adiktif di internet. 
ISBN: 978-602-72362-7-1

Kecanduan game online adalah perilaku yang bersifat kronis dan kompulsif untuk memuaskan diri pada permainan yang dimainkan dengan koneksi internet hingga menimbulkan masalah dalam kehidupan sehari-hari. Permasalahan yang timbul sifatnya merugikan diri sendiri, meskipun demikian tidak membuat pemain berusaha untuk menghentikan atau mengurangi aktivitasnya bermain game online karena merasa sulit untuk keluar atau berhenti memainkan game online (Pratiwi dkk, 2012:3). Jadi, bagi para pecandu game online akan sulit untuk mengontrol atau mengendalikan dirinya dan berhenti atau setidaknya mengurangi waktu dan kuantitas bermain game onlinenya.

Konseling kelompok adalah suatu bantuan kepada individu dalam situasi kelompok yang besifat pencegahan, penyembuhan, serta diarahkan pada pemberian kemudahan dalam perkembangan dan pertumbuhannya. (Nurihsan dalam Kurnanto, 2013: 7). Konseling kelompok dianggap sangat efektif karena dengan dinamika kelompok yang dibangun saat proses konseling dapat memaksimalkan peran setiap anggota kelompok untuk turut berpartisipasi aktif dalam kegiatan kelompok yang secara tidak langsung menjadi sarana dalam berkomunikasi dan menjalin hubungan baik serta melakukan penyesuaian diri masingmasing anggota kelompok secara inovatif. Hal ini sesuai dengan pendapat Mc Clure (dalam Kurnanto, 2013: 1) melalui kelompok individu mencapai tujuannya dan berhubungan dengan yang lainnya dengan cara yang inovatif dan produktif.

Kontrol diri sendiri menurut Berk Gunarsa adalah kemampuan individu utuk menahan keinginan atau dorongan sesaat yang bertentangan dengan tingkah laku yang tidak sesuai dengan norma sosial (dalam Khairunnisa 2013:223. Kontrol diri dapat diartikan sebagai suatu aktivitas pengendalian tingkah laku. Kemampuan untuk menyusun, membimbing, mengatur dan mengarahkan bentuk perilaku yang dapat membawa individu ke arah konsekuensi positif. Kontrol diri berkaitan dengan bagaimana individu mengendalikan emosi serta dorongandorongan dalam dirinya Hurlock (dalam Khairunnisa 2013:223). Kazdin, 1994 menyebutkan kontrol diri diperlukan guna membantu mengatasi berbagai hal merugikan yang dimungkinkan berasal dari dalam maupun dari luar .(dalam Khairunnisa 2013:223). Menurut Fox \& Calkins ,kontrol diri merupakan kapasitas 45t56dalam "self", yang dapat digunakan untuk mengontrol variabel variabel luar yang menentukan tingkah laku. (dalam Novianti, 2014). 
ISBN: 978-602-72362-7-1

Sedangkan teknik kontrol diri di sini merupakan suatu usaha atau prosedur yang akan dijalankan untuk mengarahkan dan mengontrol perilaku.

Di mana nantinya subjek akan terlibat dalam beberapa atau keseluruhan prosedur treatmen untuk mencapai tujuan yang diinginkan (Baumeister, Vohs \& Tice, 2007).

Hasil penelitian Widarti (2010) menunjukkan bahwa kemampuan mengontrol diri mempengaruhi tingkat kecanduan game online. Individu yang mempunyai diri baik mampu mengendalikan diri dalam bermain game online, sehingga mampu menggunakan game online sesuai dengan kebutuhan dan kapasitasnya sebagai hiburan. Sedangkan individu yang mempunyai kontrol diri kurang baik maka kemampuan untuk mengendalikan diri juga kurang, sehingga berlebihan dalam bermain game online yang menyebabkan kecanduan. Semakin tinggi kontrol diri seseorang maka semakin rendah kecanduan game onlinenya, sebaliknya semakin rendah kontrol dirinya semakin tinggi kecanduan game onlinenya. Dalam meningkatkan kemampuan kontrol diri siswa maka perlu diberikan teknik kontrol diri yang dalam tahapan prosedurnya ada cara mengelola situasi, mengelola perilaku dan mengelola konsekuensi agar siswa dapat mengendalikan diri dalam bermain game online dan mengarahkan perilakunya ke arah yang lebih positif. Berdasar pendapat para ahli, maka dapat disimpulkan kontrol diri adalah kemampuan seseorang dalam mengontrol perilaku, mengontrol pikiran dan mengontrol keputusan sesuai dengan situasi dan kondisi yang dapat membawa individu ke arah konsekuensi positif.

$$
\text { Berdasarkan latar belakang }
$$
permasalahan di atas, maka permasalah yang akan diajukan dalam proposal skripsi ini adalah Apakah terdapat Pengaruh Konseling Kelompok dengan Pendekatan Behavioral Teknik Kontrol Diri untuk Mengurangi Kecanduan Game Online pada siswa kelas X TKR SMK Muhammadiyah 6 Rogojampi Semester Genap Tahun Ajaran 2017/2018. Apakah terdapat perbedaan Pengaruh Konseling Kelompok dengan Pendekatan Behavioral Teknik Kontrol Diri untuk Mengurangi Kecanduan Game Online pada siswa kelas X TKR SMK Muhammadiyah 6 Rogojampi Semester Genap Tahun Ajaran 2017/2018.

\section{KAJIAN LITERATUR DAN PENGEMBANGAN HIPOTESIS}

Soetjipto 2007 menyebutkan bahwa kecanduan adalah suatu gangguan yang sifatnya kumat-kumattan ataun kronis, 
ISBN: 978-602-72362-7-1

ditandai dengan perbuatan kompulsif yang dilakukan seseorang secara berulang-ulang untuk mendapatkan pada kepuasan aktivitas kepuasaan tertentu. Instilah kecanduan juga digunakan untuk menyebut ketergantungan pada permasalahan sosial seperti judi, kompulsif makan, adiksi shopping, bahkan internet khususnya game online (dalam Pratiwi dkk, 2012:2).

Lemmers dkk

mendefinisikan kecanduan game sebagai penggunaan berlebihan dan kompulsif pada vidio game atau game komputer yang mengakibatkan masalah sosial danatau emosional. Meski mengalami masalah ini, pemain tidak dapat mengontrol penggunaan tersebut. Berdasarkan penjelasan diatas dapat disimpulkan bahwa kecanduan game online adalah salah satu bentuk kecanduan yang bersifat non-physical, ditunjukan dengan perilaku tidak sehat yang kompulsif atau perilaku yang dilakukan secara terus-menerus dalam memainkan game online untuk mendapat kepuasan tersendiri sehingga akan sulit berhenti atau membatasinya meski perilaku tersebut menyebabkan beberapa masalah sosial atau emosional.

Salah satu game yang sedang diminati oleh pemain game online adalah Mobile Legends. Mobile legends merupakan sebuah game online dengan Platform PC (Personal Computer), yang berjenis MOBA (Massive Online Battle Arena), dimana setiap pemain mengontrol representasi dalam game, yaitu karakter yang dimainkan. Setiap tim memiliki tujuan untuk pengelolaan sumber daya dan penciptaan pasukan pembantu (Bovenkamop dkk, 2013:2). Mobile Legends dikembangkan dan diterbitkan oleh Riot games pada tanggal 11 Juli 2016.

Tahapan-tahapan konseling kelompok pada umumnya ada empat tahap perkembangan dalam konseling kelompok, yang meliputi: 1) tahap pembuentukan, 2) tahap peralihan, 3) tahap pelaksanaan kegiatan, dan 4) tahap pengakhiran. Masing-masing tahap tersebut memiliki karakteristik tertentu (Prayitno, 2004).

Kontrol diri diartikan sebagai kemampuan untuk menyusun, membimbing, mengatur, dan mengarahkan bentuk perilaku yang dapat membawa ke arah konsekunsi positif. Selain itu juga meruopakan kecakapann individu dalam kepekaan membaca situasi di lingkungannya dan kemampuan mengontrol dan mengelola faktor-faktor perilaku sesuai dengan situasi dan kondisi dalam menampilkan diri dalam melakukan sosialisasi. (Ghufron \& Risnawita, 2010:21).

Rodin, menyebutkan bahwa kontrol diri adalah perasaan bahwa seseorang dapat membuat keputusan dan 
ISBN: 978-602-72362-7-1

mengambil tindakan yang efektif untuk menghasilkan akibat yang diinginkan (Utami \& Sumaryono 2008:48). Berdasarkan definisi-definisi di atas dapat disimpulkan bahwa kontrol diri adalah kemampuan individu untuk mengedalikan, mengatur dan mengarahkan perilaku dan dorongandorongan dalam dirinya dan mengarahkannya ke arah konsekunsi positif.

Berdasarkan landasan teori diatas, maka hipotesis yang diajukan dalam penelitian ini adalah (1) Konseling kelompok dengan Pendekatan behavioral teknik kontrol diri berpengaruh untuk mengurangi Kecanduan game online pada siswa kelas X SMK SMK Muhammadiyah 6 Rogojampi. (2) Terdapat perbedaan penurunan kecanduan game online antara kelompok eksperimen dan kelompok kontrol.

\section{METODE PENELITIAN}

Menurut Sugiyono (2010:119), "Populasi adalah wilayah generalisasi yang terdiri atas obyek/subyek yang mempunyai kualitas dan kualitas dan karakteristik tertentu yang ditetapkan oleh peneliti untuk dipelajari dan kemudian ditarik kesimpulan". Populasi yang digunakan dalam penelitian ini adalah siswa kelas $\mathrm{X}$ TKR sejumlah 266 siswa di SMK Muhammadiyah 6 Rogojampi Tahun Ajaran 2017/2018.
Pengambilan Sampel penelitian ini adalah Siswa SMK kelas X TKR yang terindikasi rendahnya kontrol diri, dengan menggunakan konseling kelompok behavioral teknik kontrol diri siswa dapat meningkatkan kontrol dirinya. Teknik pengambilan sampel ini menggunakan Purposive Sampling.

Metode pengumpulan ini menggunakan metode observasi, wawancara, dan kuisoner. Penyebaran kuisioner kecanduan game online di berikan kepada 266 siswa kelas X TKR SMK Muhammadiyah 6 Rogojampi. Sebelum kuisioner di sebarkan dilakukan uji validitas isi yaitu validitas yang ditentukan oleh derajat reprentativitas butir-butir instrument yang disusun telah mewakili keseluruhan materi yang hendak diukur tersebut. Untuk mengetahui validitas isi kuesioner kecanduan game online yang digunakan, maka perlu dilakukan penilaian ahli (expert judgement) oleh dua orang ahli. Setelah analisis validitas isi tersebut, dilanjutkan dengan melakukan uji validitas butir melalui analisis butir. Suatu angket (kuesioner) dikatakan valid jika pernyataan/pernyataan pada suatu kuesioner mampu untuk mengungkapkan sesuatu yang akan di ukur oleh kuesioner tersebut (Nurkancana, 1990: 232). Setelah validitas isi dan validitas butir 
ISBN: 978-602-72362-7-1

dilakukan, maka selanjutnya dilakukan uji reabilitas (keandalan). Suatu kuisioner dikatakan reliabel "apabila tes tersebut menunjukkan hasil-hasil yang mantap". (Nurkanca, 1993:144).

Setelah mendapat data kusioner kecanduan game online akan dilakukan analisis data secara deskriptif. Data instrumen kecanduan game online dianalisis secara deskriptif dan dinyatakan dengan jenjang kualifikasi. Jenjang kualifikasi dikategorikan berdasarkan skor rata-rata $(\bar{X})$, mean ideal (Mi), dan standart deviasi ideal $\left(\mathrm{SD}_{\mathrm{i}}\right)$. Uji prasyarat analisis yaitu (1) uji normalitas adalah sebaran data dilakukan untuk meyakinkan bahwa data yang dihasilkan dalam penelitian benarbenar berdistribusi normal, sehingga uji hipotesis dapat dilakukan. (2) Uji homogenitas digunakan untuk mengetahui apakah kelompok-kelompok sampel berasal dari populasi yang sama. Kesamaan asal sampel ini dibuktikan dengan adanya kesamaan varians kelompok-kelompok yang membentuk sampel tersebut. (3) Uji Hipotesis Sebagai langkah lebih lanjut dalam penelitian ini, dilakukan suatu produser analisis terhadap data-data yang diperoleh peneliti. Tujuan dari analisis data ini adalah mengungkapkan apa yang ingin diketahui dari peneliti. Dalam menganalisis data yang diperoleh selama melakukan penelitian, penulis menggunakan dua analisis statistik, antara lain (1) analisis statistik correlated data/paired sampel t-test dan (2) analisis statistik uncorrelated data/independent sampel t-test.

Dasar pengambilan keputusannya adalah : (a) Jika t hitung > t tabel, maka $\mathrm{H}_{\mathrm{o}}$ ditolak, (b) Jika $\mathrm{t}$ hitung $<\mathrm{t}$ tabel, maka $\mathrm{H}_{\mathrm{o}}$ diterima. Berdasarkan nilai probabilitinya : (1) Jika probabilitas > 0,05 maka $\mathrm{H}_{\mathrm{o}}$ diterima, (2) Jika probabilitas < 0,05 maka $\mathrm{H}_{\mathrm{o}}$ ditolak. Analisis statistik correlated data/paired sampel t-test dimaksudkan untuk mengetahui efektivitas atau pengaruh dari variabel bebas terhadap variabel terikat dilihat dari perbedaan pretest dengan posttest (Seniatai, Yulianto dan Setiadi, 2005:119).

\section{RANCANGAN PENELITIAN}

Penelitian ini adalah penelitian kuantitatif dengan metode experimen. Rancangan penelitian kuantitatif ini yakni quasi experimental (ekseprimen semu). Desain penelitian ini menggunakan rancangan Non equivalent Pretest-Posttest Control Group Design. Rancangan control group design dipilih dengan pertimbangan bahwa dalam eksperimen semu, tidak memungkinkan untuk merandom subjek dalam kelompok populasi secara utuh. Selanjutnya pretest dan posttest berarti memberikan tes kepada subjek 
sebelum dan setelah perlakuan diberikan pada masing-masing kelompok. Rancangan ini dipilih karena penelitian ini merupakan penelitian terapeutik untuk mengetahui pengaruh perlakuan terhadap variabel terikat. Artinya rancangan pretest dan posttest digunakan untuk mengetahui siswa yang kecanduan game online.

\begin{tabular}{cccc}
$\mathrm{E}$ & $\mathrm{O}_{1}$ & $\mathrm{X}$ & $\mathrm{O}_{2}$ \\
& & & \\
\hline $\mathrm{K}$ & $\mathrm{O}_{1}$ & - & $\mathrm{O}_{2}$
\end{tabular}

(Sumber: Dantes, 2012:97)

Gambar 02. Desain Non Equivalent Pretest-Posttest Control Group

E : kelompok eksperimen

$\mathrm{K}$ : keompok kontrol

$\mathrm{X}$ : konseling kelompok behavioral dengan teknik kontrol diri

- : konseling kelompok tanpa teknik khusus

$\mathrm{O} 1$ : pengamatan awal, berupa pretest sebelum diberikan perlakuan.

O2: Pengamatan akhir, yaitu pemberian post test setelah diberikan perlakuan.

\section{KESIMPULAN}

Menurut Kim dkk, Game Online game atau (permainan) dimana banyak orang yang dapat bermain pada waktu yang sama melalui jaringan komunikasi online atau internet (dalam Azis 2011:3). Kecanduan game online adalah salah satu bentuk kecanduan yang bersifat non-physical, ditunjukan dengan perilaku tidak sehat yang kompulsif atau perilaku yang dilakukan secara terus-menerus dalam memainkan game online untuk mendapat kepuasan tersendiri sehingga akan sulit berhenti atau membatasinya meski perilaku tersebut menyebabkan beberapa masalah sosial atau emosional.

Tujuan dari penelitian ini adalah untuk menguji pengaruh konseling kelompok dengan pendekatan behavioral teknik kontrol diri untuk mengurangi kecanduan game online pada siswa SMK Muhamadiyah 6 Rogojampi kelas X TKR.

$$
\text { Jumlah sampel yang }
$$

digunakan adalah 20 siswa yang kecanduan game online. Metode penelitian ini menggunakan rancangan Non equivalent PretestPosttest Control Group Design. Rancangan ini dipilih karena penelitian ini merupakan penelitian terapeutik untuk mengetahui pengaruh perlakuan terhadap variabel terikat.

\section{DAFTAR PUSTAKA}

Anuryanti, Putri Agus Sholikha. 2016. Penerapan Teknik Self Control untuk Mengurangi Kecanduan Game Online Siswa Kelas XI SMK Negeri 1 Driyojoyo. Jurnal [online] BK FIP Universitas Negeri Surabaya. 
ISBN: 978-602-72362-7-1

(http://jurnalmahasiswa.unesa.ac.i d/index.php/jurnal-bkunesa/article/view/15042) di akses 02 April 2018

Arikunto, Suharsimi. 2006. Prosedur Penelitian: Suatu Pendekatan Praktik. Jakarta: Rineka Cipta.

Arikunto, Suharsimi. 2010. Dasar-dasar Evaluasi Pendidikan (Edisi Revisi). Jakarta: Bumi Aksara.

Corey, Gerald (Terjemahan E. Koswara.). 2010. Teori dan Praktek Konseling dan Psikoterapi. Bandung: PT. Refika Aditama.

Dantes, Nyoman. 2012. Metode Penelitian. Yogyakarta: Penerbit Andi.

Dantes, Nyoman. 2014. Analisis dan Desain Eksperimen. Singaraja: Universitas Pendidikan Ganesha.

Hartono, Soedarmadji $\quad$ B. 2012. Psikologi Konseling, Jakarta: Kencana Prenada Media Group.

http://direktori.madrasah.kemenag.go.id/ media/files/UU20TH2003.pdf di akses 10 April 2018

https://www.liputan6.com/tekno/read/31 25191/5-hero-di-mobile-legendsberasal-dari-asia-siapa-saja di akses 25 April 2018

Komalasari, Gantina dkk. 2011. Teori dan Teknik Konseling. Jakarta: PT. Indeks.
Koyan, I Wayan. 2012. Statistik Pendidikan (Teknik Analisis Data Kuantitatif). Singaraja: Undiksha Press.

Masyita, A.R. 2016. Pengaruh kontrol diri terhadap kecanduan game online pada pemain Dota 2 Malang. Skripsi [online] Fakultas Psikologi Universitas Islam Negeri Maulana Malik Ibrahim Malang. (http://etheses.uinmalang.ac.id/3708/1/12410025.pdf di akses 10 April 2018)

Noor, Juliansyah. 2010. Metodelogi penelitian. Jakarta: Kencana Prenada Media Group.

Nursalim, M 2015. Pengembangan profesi bimbingan dan konseling. Jakarta Gelora Aksara Pratama.

Prasetiawan, Hardi. 2016. Upaya mereduksi kecanduan game online melalui layanan konseling kelompok. Jurnal [online] Prodi Bimbingan Konseling Fakultas Keguruan dan Ilmu Pendidikan Universitas Ahmad Dahlan. (https://media.neliti.com/media/pub lications/162854-ID-upayamereduksi-kecanduan-game-online-

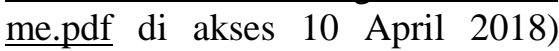

